aUniversidade Estadual de Maringá, Departamento de Química, campus sede, Avenida Colombo 5790, CEP 87020-900, Maringá-PR, Brasil.

'Universidade Tecnológica Federal do Paraná, Campus Apucarana, Programa de Graduação de Engenharia Química, Rua Marcílio Dias 635, CEP 96812-460, Apucarana-PR, Brasil.

`E-mail: jesuivv@gmail.com

Recebido em: 20 de Março de 2021

Aceito em: 5 de Agosto de 2021

Publicado online: 3 de Fevereiro de 2022

\section{Assessment of Moringa oleifera Lam. Seeds Potential as an Adsorbent Material for Soybean Oil Bleaching}

\author{
Avaliação do Potencial das Sementes de Moringa oleifera Lam. como \\ um Material Adsorvente para o Branqueamento de Óleo de Soja
}

\author{
Patricia M. Souza, ${ }^{\circledR(}$ Marilia B. Galuch, $\left.{ }^{\circledR(}\right)$ Ana P. Lopes, ${ }^{a}$ Jessica S. Pizzo, ${ }^{a}{ }^{(1)}$ Matheus C.

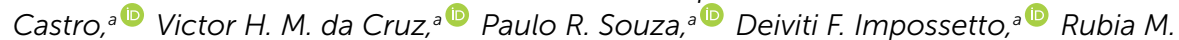 \\ Suzuki, ${ }^{\circ}$ (i) Jesuí V. Visentainer ${ }^{a, *(1)}$
}

\begin{abstract}
During the refining process of vegetable oils, the removal of pigments occurs in the bleaching stage, in which oil-adsorbent agents are used. Although various types of adsorbent materials are commercially available, alternative bleaching agents are being constantly investigated to increase the efficiency of this step. This work used seeds of Moringa oleifera Lam. in natura and in the form of activated charcoal to remove chlorophyll from soybean oil. The techniques used for this purpose were infrared with Fourier transform (FTIR), thermogravimetric analysis (TGA), chlorophyll by ultraviolet-visible (UV-VIS) spectroscopy, titratable acidity, gas chromatography with a flame ionization detector (GC-FID), and direct infusion by electrospray ionization mass spectrometry in positive ion mode (ESI(+)-MS). The results obtained showed that the defatted seeds of Moringa did not have the potential to remove chlorophyll from the oil. Activated charcoal produced from seeds, on the other hand, was effective as a bleaching agent, removing $97.53 \%$ of the chlorophyll content of the treated soybean oil. Besides, the use of coal obtained from Moringa seeds did not significantly change the composition of fatty acids, therefore, the use of coal as Moringa seeds is indicated. As a result, the activated charcoal from Moringa seeds has the potential to be used during the refining process of soybean oil.
\end{abstract}

Keywords: Soybean oil; bleaching; moringa seeds; adsorbent agents; charcoal; environmental impact.

\section{Introduction}

Vegetable oils are widely used by food industries; however, they can also be used as raw material for several products such as inks, lubricants, fuels, and drugs. There are several vegetable sources from which oils can be obtained, therefore, the extraction methods have been improved through scientific and technological development. ${ }^{1}$

In industrial scale, production and refinement of vegetable oils, such as soybean oil, for instance, include several steps such as oil extraction, degumming, neutralization, bleaching, and deodorization which are done to improve the oil's appearance, flavor, odor, and oxidative stability. Specifically, the oil's bleaching allows the removal of pigments such as chlorophyll, carotenoids, and xanthophylls. ${ }^{2}$

The efficiency of the bleaching step is affected by several factors, for example, the adsorbent's properties; nature of the refined oil's pigments; temperature; and technique employed. Thus, selecting an adsorbent with adequate efficiency and selectivity is vital to successfully bleach the vegetable oil. ${ }^{3}$

Despite the substantial amount of adsorbent materials commercially available in the market, such as silica gel, activated charcoal, aluminum oxide, aluminum silicate, acid-activated clay, and zeolites, alternative bleaching agents, such as rice husk ash silicates, sugarcane bagasse, and pineapple plant leaves are constantly under evaluation as to enhance the efficacy as well as reduce costs and environmental pollution of this step, as it is a safety concern associated with some adsorbents. ${ }^{2,4-6}$

Moringa (Moringa oleifera Lam.), from the Moringaceae family, is an Indian-northwest native species, widely cultivated in tropical and subtropical areas, ${ }^{7}$ with seeds extensively used in alternative processes to acquire drinking water ${ }^{8-9}$ due to its adsorbent potential ${ }^{8,10}$ Furthermore, a study already reported the use of Moringa oleifera Lam. seeds as an adsorbent for heavy metals in alcohol-based fuels. ${ }^{11}$ However, to the best of our knowledge, no study investigated using Moringa oleifera Lam. seeds as bleaching material of vegetable oils.

Hence, this study aims to assess the bleaching process of soybean oil using Moringa oleifera 
Lam. seeds by fourier-transform infrared spectroscopy (FTIR), thermogravimetric analysis (TGA), ultravioletvisible spectroscopy (UV-VIS) analysis of chlorophyll content, titratable acidity, gas chromatography with flame ionization detector (GC-FID), and direct infusion electrospray ionization mass spectrometry (ESI-MS).

\section{Material and Methods}

\subsection{Reagents and materials}

Chloroform, isooctane, methanol, potassium bromide, ethanol, potassium hydroxide, potassium hydrogen phthalate, phenolphthalein, and sodium chloride (all analytical grade) were purchased from Synth (São Paulo, Brazil). Sodium hydroxide, ammonium chloride, and sulfuric acid (all analytical grade) were purchased from Dinâmica (São Paulo, Brazil). Methanol and Chloroform (HPLC-grade) were acquired from J.T. Baker ${ }^{\circledR}$ (Philipsburg, United States) and Riedel-de Haën (Seelze, Lower Saxony, Germany), respectively. Ammonium formate was purchased from Sigma-Aldrich (Darmstadt, Germany). For GC-FID analysis, all reagents and chemicals were analytical grade. HPLC-grade solvents were used for ESI-MS analysis.

\subsection{Samples}

Moringa oleifera Lam. seeds were bought from local commerce in the city of Maringá (Paraná, Brazil). Neutralized soybean oil (OSN) was donated by Cocamar Cooperativa Agroindustrial, a vegetable oil industry of Maringá (Paraná, Brazil). Commercial activated charcoal (CPA) was acquired from Sigma-Aldrich (Darmstadt, Germany).

\subsection{Proximate composition of Moringa oleifera Lam. seeds}

Moisture, ash, crude protein, and carbohydrate content of Moringa oleifera Lam. seeds were determined following techniques described by Gallão et al. ${ }^{12}$ for food analysis.

Lipid extraction was performed by Bligh and Dyer ${ }^{13}$ method, employing a mixture of chloroform-methanol-water $(2: 2: 1.8 \mathrm{v} / \mathrm{v} / \mathrm{v})$, with modifications on solvents' volume. $3.2 \mathrm{~g}$ of lyophilized seeds and $11.8 \mathrm{~mL}$ of distilled water, employed to adjust humidity content, were homogenized for 5 minutes under magnetic stirring with $15 \mathrm{~mL}$ of chloroform and $30 \mathrm{~mL}$ of methanol. Then, $15 \mathrm{~mL}$ of chloroform was added and stirring maintained for 2 minutes. At last, $15 \mathrm{~mL}$ of distilled water was added, and the solution stirred for another 5 minutes. After homogenization was completed, the mixture was filtered on a Whatman $\mathrm{n}^{\circ} 1$ paper in a vacuum pumped Büchner funnel. The filtered solution was transferred to a $250 \mathrm{~mL}$ separatory funnel until complete phase separation. Then, the organic phase was transferred to a previously weighted flat-bottomed flask for solvent evaporation on a rotary evaporator assisted by a $30{ }^{\circ} \mathrm{C}$ water bath. Total lipid content was calculated by gravimetry.

\subsection{Preparation of activated charcoal from defatted Moringa oleifera Lam. seeds}

Activated charcoal of defatted seeds of Moringa oleifera Lam. (CMO) was prepared in two steps: carbonization and chemical activation by $\mathrm{NaOH}$.

\subsection{Carbonization process}

Carbonization was performed with $15.0 \pm 0.10 \mathrm{~g}$ of a precursor (defatted Moringa oleifera Lam. seeds - MOD), $1.20 \mathrm{~mm}$ granulometry (16 mesh), being placed in a stainless steel horizontal reactor with $180 \mathrm{~cm}^{3}$ volume and removable lids with holes for gases inlet and outlet. This reactor was placed in a Zezimag FHMP muffle furnace programmed to reach $450{ }^{\circ} \mathrm{C}$ with a $10{ }^{\circ} \mathrm{C} \mathrm{min}^{-1}$ heating ramp and a $100 \mathrm{~mL} \mathrm{~min}^{-1} \mathrm{~N}_{2}$ gas flow. The precursor was kept at the muffle furnace for 2 hours, after the desired temperature was reached, to obtain the carbonized material (MC).

\subsection{Chemical activation process}

Chemical activation step was performed employing a 3:1 $\left(\mathrm{m} \mathrm{m}^{-1}\right) \mathrm{NaOH}: \mathrm{MC}$ ratio. The mixture was homogenized under magnetic stirring for 2 hours, and $10 \mathrm{~mL}$ of distilled water was added for each fraction of $\mathrm{NaOH}$ :MC. After homogenization was completed, the mixture was placed on an oven at $130{ }^{\circ} \mathrm{C}$ for 24 hours. Then, the dry sample was placed at a muffle furnace with a $100 \mathrm{~cm}^{3} \mathrm{~min}^{-1} \mathrm{~N}_{2}$ gas flow and a $10{ }^{\circ} \mathrm{C} \mathrm{min}^{-1}$ heating ramp to reach $750{ }^{\circ} \mathrm{C}$. The dry sample was maintained at the muffle for 1.5 hours after the desired temperature was reached. After cooling off, the material was washed with water and $\mathrm{HCl} 0.1 \mathrm{~mol} \mathrm{~L}^{-1}$ to reach a pH of 6.5, therefore, guaranteeing complete removal of the activating agent. Finally, after oven-drying at $110{ }^{\circ} \mathrm{C}$ for 4 hours, the activated charcoal of defatted seeds of Moringa oleifera Lam. (CMO) was obtained.

\subsection{Activated charcoal characterization}

\subsubsection{Fourier-Transform Infrared Spectroscopy (FTIR)}

FTIR spectra of samples CPA and CMO were acquired utilizing a Fourier-transform infrared spectrophotometer (Thermo Fisher Scientific, Nicolet iZ10 model, USA) operating from 400 to $4000 \mathrm{~cm}^{-1}, 4 \mathrm{~cm}^{-1}$ resolution, and acquisition rate of 64 scans $\mathrm{min}^{-1}$. Samples were prepared as Potassium Hydroxide pellets (KBr; 0.25\%).

\subsubsection{Thermogravimetric analysis (TGA)}

Thermal stability of samples was evaluated with a thermogravimetric analyzer (Netzsch, Shimadzu, TGA-50, Japan) programmed to reach $650{ }^{\circ} \mathrm{C}$ with a $10{ }^{\circ} \mathrm{C} \mathrm{min}^{-1}$

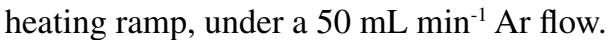




\subsection{Charcoal applicability}

\subsubsection{Neutralized soybean oil bleaching}

$20 \mathrm{~mL}$ of neutralized soybean oil were homogenized by magnetic stirring for 20 minutes, at $80^{\circ} \mathrm{C}$, with $0.8 \mathrm{~g}$ of adsorbent material (CMO, CPA, and MOD). The mixture was then centrifuged (HARRIER 18/80 Refrigerated) for 15 minutes until complete phase separation. Neutralized soybean oil bleached by CMO (CMOB), CPA (CPAB), and MOD (MODB) were collected and filtered with a syringe (hypodermic needleless syringe, bd Plastipak, $3 \mathrm{~mL}$ ) and stored until analysis of chlorophyll content, titratable acidity, triacylglycerols profile (TAGs), and fatty acid composition.

\subsubsection{Chlorophyll content}

Chlorophyll content of bleached soybean oil samples (CMOB, CPAB, and MODB) was determined utilizing a UV-VIS spectrophotometer (Thermo Fisher Scientific, Genesys 10-S) operating on three distinct wavelengths, 710,670 , and $630 \mathrm{~nm}$, as described by Alves et al. ${ }^{11}$ method. Chlorophyll content was calculated using the equation (1):

$$
C=\frac{\frac{A_{670 \mathrm{~nm}}-\left(A_{630 \mathrm{~nm}+} A_{710 \mathrm{~nm}}\right)}{2}}{F \times L}
$$

where: $C$ : Chlorophyll content ( $\mathrm{mg} \mathrm{kg}^{-1}$ or $\left.\mathrm{ppm}\right) ; A$ : Absorbance; $L$ : Optical path length; $F$ : spectrophotometerspecific correction factor.

\subsubsection{Titratable acidity}

Titratable acidity was performed by dissolving $0.1000 \pm 0.001 \mathrm{~g}$ of bleached soybean oil (CMOB, $\mathrm{CPAB}$, and MODB) in $10 \mathrm{~mL}$ of anhydrous ethanol. Samples were then titrated with a potassium hydroxide $0.01 \mathrm{~mol} \mathrm{~L}^{-1}$ solution, previously standardized with a standard solution of potassium hydrogen phthalate, and 2 drops of phenolphthalein $1 \%$ as a chemical indicator.

Titrations were done in triplicate and titratable acidity calculated using equations 2 and $3 .^{14}$

$$
\begin{gathered}
A=\frac{V \times f}{m} \times 5,6 \\
f=\frac{C_{\mathrm{KOH}_{r}}}{C_{\mathrm{KOH}_{t}}}
\end{gathered}
$$

where: $A$ : Titratable acidity; $V$ : Volume of standard solution of $\mathrm{KOH}(\mathrm{mL}) ; m$ : Sample mass $(\mathrm{g}) ; f$ : Standard solution correction factor; $C_{\text {КОНr }}$ : real concentration of the $\mathrm{KOH}$ solution; $C_{\mathrm{KOH}}$ : Theoretical concentration of the $\mathrm{KOH}$ solution $\left(0.01 \mathrm{~mol} \mathrm{~L}^{-1}\right)$.

\subsection{Gas chromatographic analysis}

\subsubsection{Esterification/transesterification}

Fatty acid esterification and transesterification of samples CMOB, CPAB, MODB, and OSN were obtained according to the methodology proposed by Hartman e Lago $^{15}$ with modifications by Maia and Rodrigez-Amaya. ${ }^{16}$

Approximately $0.025 \mathrm{~g}$ of oil was weighed and mixed with $4 \mathrm{~mL}$ of a $\mathrm{NaOH} / \mathrm{MeOH} 0.5 \mathrm{~mol} \mathrm{~L}^{-1}$. The mixture was heated for 5 minutes in a $100{ }^{\circ} \mathrm{C}$ water bath, cooled in running water, and mixed with $5 \mathrm{~mL}$ of esterification solution $\left(\mathrm{H}_{2} \mathrm{SO}_{4} / \mathrm{MeOH}\right.$ and $\left.\mathrm{NH}_{4} \mathrm{Cl}\right)$ before being heated again for 5 minutes at the same temperature. $4 \mathrm{~mL}$ of a saturated sodium chloride solution and $2 \mathrm{~mL}$ of isooctane were then added after cooling on running water. The mixture was agitated for 30 seconds after the addition of each reagent. The solution was stored at $-20{ }^{\circ} \mathrm{C}$ for 24 hours. At last, the upper phase, containing fatty acids methyl esters (FAMEs), was collected for analysis on a gas chromatograph coupled with a flame ionization detector (GC-FID).

\subsubsection{Fatty acid composition by GC-FID}

FAMEs were separated by a Thermo Scientific Trace Ultra 3300 gas chromatograph, equipped with a flame ionization detector, split/splitless injection system, and a fused silica capillary column (CP-7420, Select FAME, $100 \mathrm{~m}$ long, internal diameter of $0.25 \mathrm{~mm}$, and a $0.25 \mu \mathrm{m}$ cyanopropyl thin film as stationary phase). A $1.2 \mathrm{~mL} \mathrm{~min}^{-1}$ and a $30 \mathrm{~mL} \mathrm{~min}^{-1}$ gas flow were used for the carrier $\left(\mathrm{H}_{2}\right)$ and make-up $\left(\mathrm{N}_{2}\right)$ gases, respectively. Gas flows of 35 e 350 $\mathrm{mL} \min ^{-1}$ were used for flame gases $\mathrm{H}_{2}$ and synthetic air, respectively. Injections were made employing a 1:80 split ratio and a $2 \mu \mathrm{L}$ volume. The injector and detector operated at 200 and $240{ }^{\circ} \mathrm{C}$, respectively. Chromatographic analysis was performed in 30 minutes with the following heating programming: 1) $165{ }^{\circ} \mathrm{C}$ for 7 minutes; 2) a $4{ }^{\circ} \mathrm{C} \min ^{-1}$ heating ramp from 165 to $185{ }^{\circ} \mathrm{C}$; 3) $185{ }^{\circ} \mathrm{C}$ for 4.67 minutes; 5) a $6{ }^{\circ} \mathrm{C} \mathrm{min}{ }^{-1}$ heating ramp from 185 to $235^{\circ} \mathrm{C}$; 5) $235^{\circ} \mathrm{C}$ for 5 minutes. ${ }^{17}$

FAMEs were identified by comparing retention times on samples and a FAMEs standard (F.A.M.E. Mix, C4-C24, Sigma-Aldrich, Darmstadt, Germany). FA content was expressed as relative percentage, automatically calculated by the Chromquest ${ }^{T M} 5.0$ software. ${ }^{18}$

\subsection{Sample preparation and triacylglycerol determination}

TAGs profiles were acquired according to da Silveira et al. ${ }^{17}$ a solution was prepared by diluting $50 \mu \mathrm{L}$ of oil on $950 \mu \mathrm{L}$ of chloroform. To $5 \mu \mathrm{L}$ of this solution, $1 \mathrm{~mL}$ of methanol/chloroform 9:1 ( $\left.\mathrm{v} \mathrm{v}^{-1}\right)$ was added. $20 \mu \mathrm{L}$ of ammonium formate $0.10 \mathrm{~mol} \mathrm{~L}^{-1}$ was added to the final solution to improve adduct ion's formation.

Analyses were performed in a triple quadrupole mass spectrometer (XEVO TQ-D, Waters, Massachusetts, United States) equipped with electrospray ionization (ESI) 
operating in positive ion mode. Lipid samples were infused directly in the mass spectrometer. Operating conditions were: Capillary and cone voltage of $3.00 \mathrm{kV}$ and 35.00 $\mathrm{V}$, respectively, source temperature set at $150{ }^{\circ} \mathrm{C}$, and a $450 \mathrm{~L} \mathrm{~h}^{-1}$ flow of desolvation gas at $250{ }^{\circ} \mathrm{C}$.

\subsection{Statistical analysis}

The results of fatty acid composition of soybean oil were submitted to statistical analysis of variance (ANOVA), and means were compared by Tukey's test using Statistica $8.0^{\circledR}$ software. Data are presented as mean \pm standard deviation $(\mathrm{SD})$ with $5 \%(\mathrm{p}<0.05)$ of significance level.

\section{Results and Discussion}

\subsection{Proximate composition of Moringa oleifera Lam. seeds}

Proximate composition of Moringa oleifera Lam. seeds is presented in Table 1.

As shown in Table 1, evaluated in natura seeds exhibited significantly low moisture content, $6.70 \pm 0.19 \%$. This result is in agreement with value found by Gallão et al. ${ }^{12}$ $(6.00 \%)$. Moisture content is related with the seed's stability, quality, and composition, ${ }^{19}$ thus, the substantially low content of Moringa oleifera Lam. seeds is greatly beneficial to the sample as it indicates a low susceptibility to degradation. Ash content, inorganic matter such as salts and minerals ${ }^{20}$ equal to $3.95 \pm 0.09 \%$ was found for in natura Moringa oleifera Lam. seeds (Table 1).

From Table 1, total lipids content of in natura seeds from Moringa oleifera Lam. were $26.71 \pm 4.10 \%$. It is observed that the total lipids content calculated in our study disagrees with findings by Gallão et al. ${ }^{12}$ and Lalas e Tsaknis, ${ }^{21} 18 \%$ and $37.2 \%$, respectively.

For crude protein content, analyses conducted by Gallão et al.,${ }^{12}$ and Passos et al.,$^{22}$ determined that crude protein make up for $40.00 \%$ and $33.9 \%$ of the proximate composition of Moringa oleifera Lam. seeds. Hence, as presented in Table 1, our result (26.76 \pm 1.47$)$ is in agreement with those reported in other studies. ${ }^{12,23}$ According to RDC $\mathrm{n}^{\circ} 54$ of November $2012^{24}$ Moringa oleifera Lam. seeds can be considered a high crude protein seed due to the content being superior to $12 \%$.

Although moisture, ash, crude protein, and total lipids content corroborate the results found in previous researches, analyzes conducted in Moringa oleifera Lam. seeds to determine their carbohydrate content showed our result $(35.88 \pm 8.27$, Table 1$)$ to be significantly different to those found by Oliveira et al. ${ }^{23} 21,12 \%$. However, ${ }^{25}$ stated that variations on the proximate composition of seeds could be related to several factors, as plant variety, climate, maturation stage, harvest time, and quantification method employed.

\subsection{Activated charcoal characterization}

\subsubsection{Fourier transform infrared spectroscopy analysis (FTIR)}

FTIR analysis provides valuable qualitative information regarding functional groups on the surface of the material. FTIR spectra of the commercial charcoal (CPA) and the prepared activated charcoal (CMO) are shown in Figure 1.

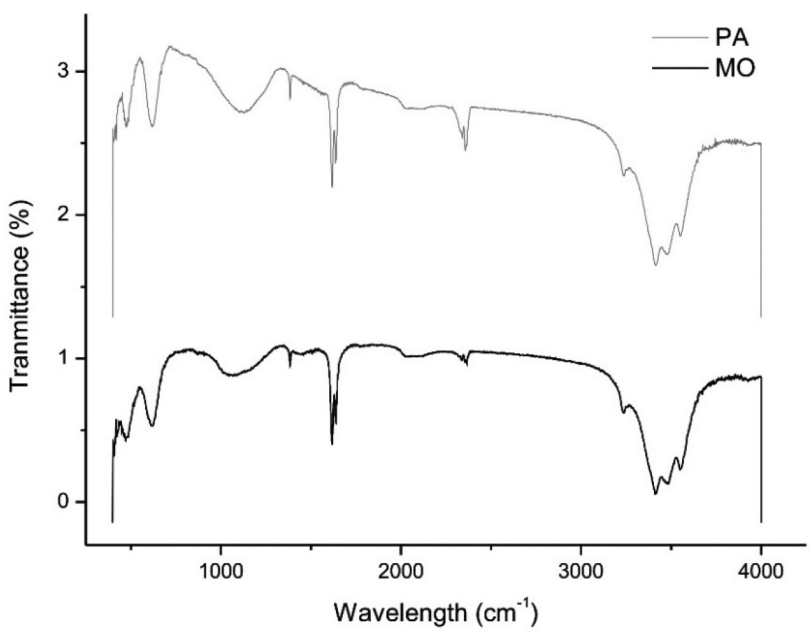

Figure 1. FTIR spectra of commercial activated charcoal (CPA) and Moringa oleifera Lam. charcoal (CMO).

Both spectra have similar profiles with vibration bands characteristic of carbonaceous materials. Furthermore, high-intensity bands observed between 3070 e $3600 \mathrm{~cm}^{-1}$ may be assigned to a combination of $\mathrm{O}-\mathrm{H}$ groups (of carboxylic acid or phenol structures) overlapping and stretching $\mathrm{N}-\mathrm{H}$ vibrations. The band at $3413 \mathrm{~cm}^{-1}$ identifies stretching vibration of aliphatic groups $-\mathrm{CH}_{2}-.^{26} \mathrm{~A}$ peak at $1611 \mathrm{~cm}^{-1}$, observed in both spectra, could represent the $\mathrm{C}=\mathrm{O}$ (aldehydes, lactone, ketones, and carboxylic acid structures) axial deformation. ${ }^{27}$ The peak at $1082 \mathrm{~cm}^{-1}$ may be assigned with stretching of C-O vibrations of carboxylate and ether structures and bending $\mathrm{O}-\mathrm{H}$ modes of phenol structures. ${ }^{26}$ Finally, the band at $621 \mathrm{~cm}^{-1}$ could be assigned to an outof-plane angular deformation of aromatic rings. ${ }^{28}$

Information acquired by FTIR analysis regarding functional groups at the activated carbon surface is essential to evaluate which structures may assist adsorption and

Table 1. Proximate composition of in natura Moringa oleifera Lam. seeds.

\begin{tabular}{ccccc}
\hline Moisture & Ash & Total lipids & Crude Protein & Carbohydrates \\
\hline $6.70 \pm 0.19 \%$ & $3.95 \pm 0.09 \%$ & $26.71 \pm 4.10 \%$ & $26.76 \pm 1.47 \%$ & $35.88 \pm 8.27 \%$ \\
\hline * Results expressed as mean \pm standard deviation (SD) of triplicate.
\end{tabular}


determine the adsorption capacity of the material. ${ }^{29,30}$ According to Volesky ${ }^{31}$ and Da Silva ${ }^{32}$ several functional groups such as carboxyl, hydroxyl, phenol, and amine may be responsible for the adsorption process in activated charcoals. Therefore, the groups identified by FTIR in the analyzed samples (CPA and $\mathrm{CMO}$ ) are possibly responsible for chlorophyll adsorption.

\subsubsection{Thermogravimetric Analysis (TGA)}

Thermogravimetric analysis monitors, under a controlled atmosphere, the sample weight loss related to time or temperature. TGA curves of in natura seeds, CPA, and $\mathrm{CMO}$ are presented in Figure 2.

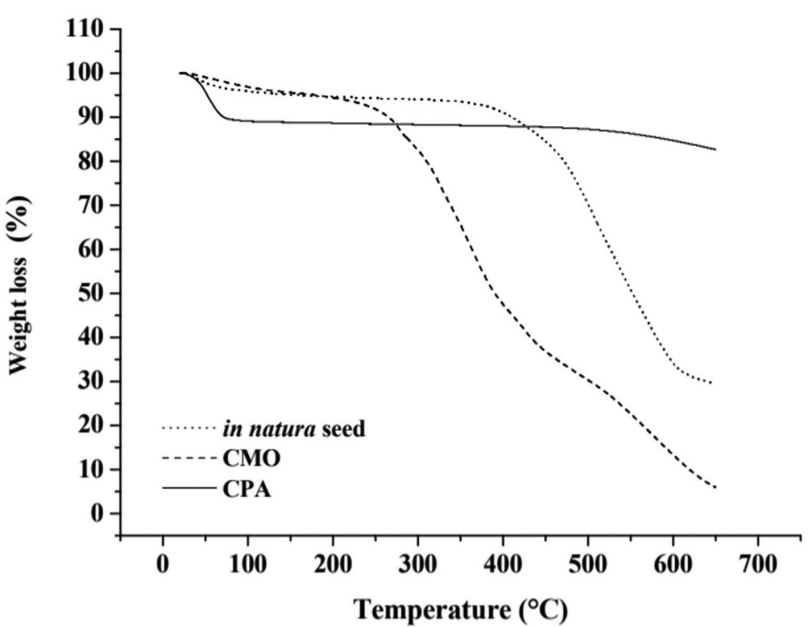

Figure 2. TGA curves acquired for commercial activated charcoal (CPA), charcoal of defatted seeds from Moringa oleifera Lam. (CMO), and in natura Moringa oleifera Lam. seeds.

At low temperatures $\left(\sim 100{ }^{\circ} \mathrm{C}\right)$ a small weight loss, possibly associated with moisture, was observed on all three curves. As presented by the results in Figure 2, the weight of in natura seeds from Moringa oleifera Lam. remains constant up to $400{ }^{\circ} \mathrm{C}$ where a substantial weight loss $\left(400-650^{\circ} \mathrm{C}\right)$ was observed. The $50 \%$ mass reduction is probably related to the degradation of hemicellulose, cellulose, and lignin molecules of the seed. ${ }^{33}$ Therefore, TGA demonstrates that in natura seeds have poor thermal stability since they lost $88 \%$ of their initial weight. Between CPA and CMO, CPA showed higher thermal stability with a residual mass of $80 \%$ at $650{ }^{\circ} \mathrm{C}$, thus indicating that lignocellulosic materials were not efficiently degraded at carbonization and chemical activation steps during $\mathrm{CMO}$ production.

\subsection{Characterization of bleached soybean oils}

\subsubsection{Chlorophyll content}

Determination of chlorophyll content is vital to assess the quality of the bleached soybean oil since it provides valuable information regarding the efficiency of the bleaching step by determining if the quantity of adsorbent material employed in this stage of the refining process is enough to efficiently remove the oil's pigments. Figure 3 shows a column graph with chlorophyll content in neutralized soybean oil (OSN) and neutralized soybean oils bleached using defatted Moringa oleifera Lam. seeds (MODB), commercial activated charcoal (CPAB) and Moringa oleifera Lam. seeds activated charcoal (CMOB).

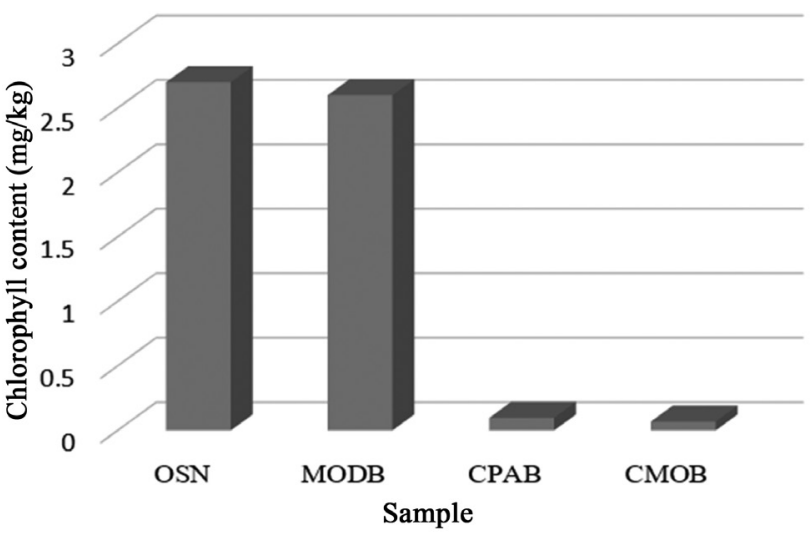

Figure 3. Chlorophyll content $\left(\mathrm{mg} \mathrm{kg}^{-1}\right)$ in neutralized soybean oil (OSN); and oils bleached by defatted seeds from Moringa oleifera Lam. (MODB), commercial activated charcoal (CPAB) and Moringa oleifera Lam. seeds activated charcoal (CMOB)

From figure 3, OSN is the sample with the highest chlorophyll content $\left(2.68 \mathrm{mg} \mathrm{kg}^{-1}\right)$. Thus, OSN will be considered as "treatment 0 " and used to evaluate the efficiency of the bleaching step in samples MODB, CPAB, and CMOB. Result obtained for treatment 0 was expected since the vegetable oil was not bleached, therefore the pigments responsible for the oil's colors, such as chlorophyll, xanthophyll, and carotenoids, were not removed. ${ }^{2}$

MODB, soybean oil bleached using Moringa oleifera Lam. seeds, showed lower chlorophyll content (approximately $2.63 \mathrm{mg} \mathrm{kg}^{-1}$ ) compared to OSN. However, as chlorophyll content of both samples does not differ substantially, bleaching of soybean oil employing Moringa oleifera Lam. seeds only provided unsatisfactory results.

Regarding CPAB, a significant decrease in chlorophyll content was obtained compared to OSN, 0.097 versus $2.68 \mathrm{mg} \mathrm{kg}^{-1}$, respectively. Thus, treatment with CPA showed to be remarkably better than treatment 0 as evidenced by the $96.4 \%$ removal of oil's pigment on sample CPAB.

CMOB showed the lowest chlorophyll content $\left(0.066 \mathrm{mg} \mathrm{kg}^{-1}\right)$ among the evaluated bleached oils. Compared to treatment 0 and with CPA, CMO proved to be 97.4 and $1 \%$, respectively, better as adsorbent material for bleaching of soybean oils. CPA is a commonly used adsorbent material for oil bleaching due to its high surface activity ${ }^{5}$, thus, our results suggest $\mathrm{CMO}$ as a better bleaching agent with similar properties to CPA. According to Gallão et al.,${ }^{12}$ the high protein content in seeds from Moringa oleifera $\mathrm{Lam}$. assists the bleaching process because of a dimeric cationic protein with a high molecular weight that acts destabilizing particles contained in the samples, such as water, and flocculates colloids by a process of 


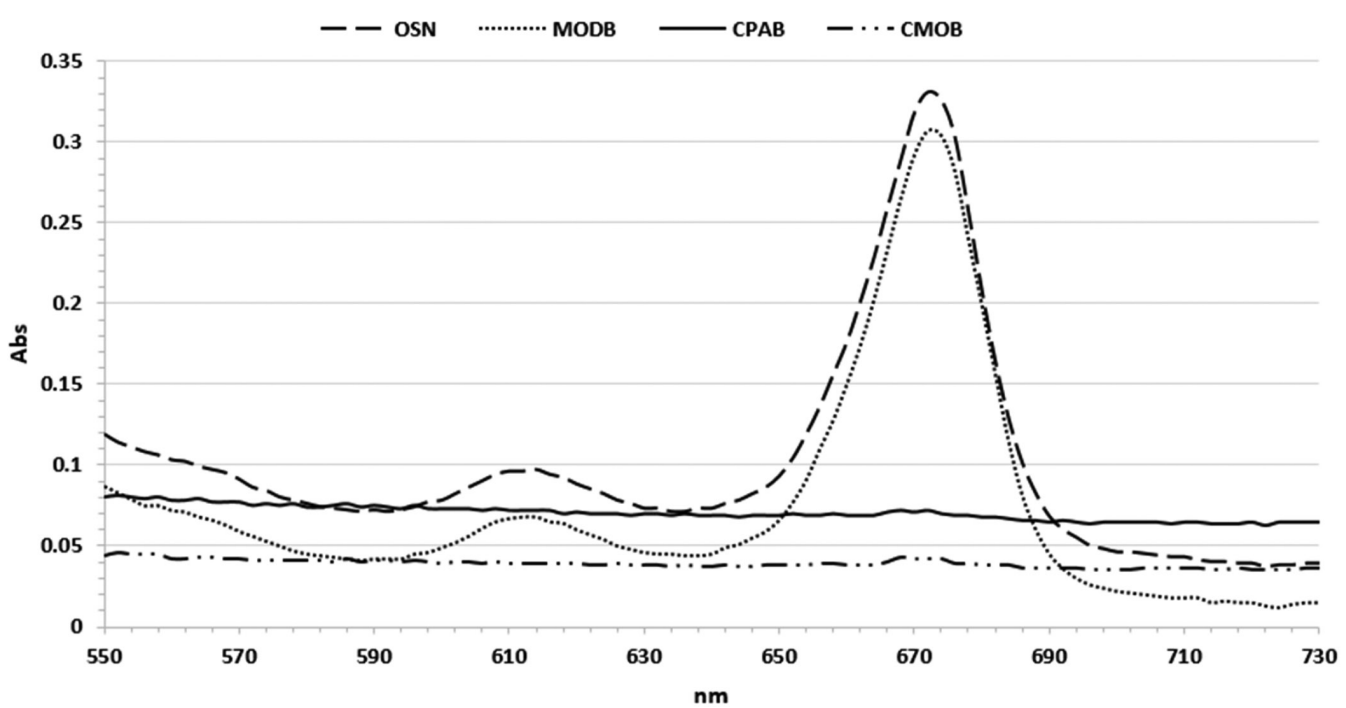

Figure 4. Full scan spectra of soybean oils bleached using different adsorbent materials. OSN: Neutralized soybean oil; MODB: Neutralized soybean oil bleached with defatted seeds from Moringa oleifera Lam.; CPAB: Neutralized soybean oil bleached employing commercial activated carbon; CMOB: Neutralized soybean oil bleached using Moringa oleifera Lam. seeds activated charcoal.

neutralization and adsorption followed by sedimentation. Full scan spectra of OSN, CPAB, CMOB, and MODB are presented in Figure 4.

As shown in figure 4, for OSN and MODB the peak at $670 \mathrm{~nm}$ indicates that soybean oil still contains chlorophyll as this is the maximum absorbance wavelength of the target analyte. Thus, the absence of such a peak on samples CPAB and $\mathrm{CMOB}$ indicates that the bleaching was successful. From figure 4, OSN shows the highest chlorophyll content, followed by MODB, CPAB, and CMOB. This result is expected since OSN was not bleached. Furthermore, $\mathrm{CMO}$ applicability as a bleaching agent for soybean oil is evidenced by the lowest chlorophyll content of CMOB out of all oils assessed.

\subsubsection{Titratable acidity}

Titratable acidity gives crucial information regarding the preservation of vegetable oils which is deeply connected to the raw material's quality, purity level, and preservation conditions. ${ }^{34}$ Therefore, titratable acidity of OSN, CPAB, $\mathrm{CMOB}$, and MODB was determined and results are presented in Figure 5.

As shown in Figure 5, titratable acidity of samples ranged from 24 to $30 \mathrm{mg} \mathrm{KOH} \mathrm{g}^{-1}$. To evaluate the efficiency of the bleaching agents being assessed in this study, the result obtained for OSN ( $25 \mathrm{mg} \mathrm{KOH} \mathrm{g}^{-1}$ ) will be referred to as "treatment 0 " and compared with those acquired for MODB, CPAB, and CMOB.

CPAB presented the lowest value for titratable acidity among all assessed samples (24 $\mathrm{mg} \mathrm{KOH} \mathrm{g}^{-1}$ ) and both CMOB and MODB samples showed the same value for titratable acidity, $30 \mathrm{mg} \mathrm{KOH} \mathrm{g}^{-1}$. Compared to treatment 0 , neutralized soybean oil bleached using CPA (CPAB) showed a slightly lower titratable acidity value. Conversely, titratable acidity values for soybean oils treated with $\mathrm{CMO}(\mathrm{CMOB})$ and MOD (MODB) were higher than treatment 0 which

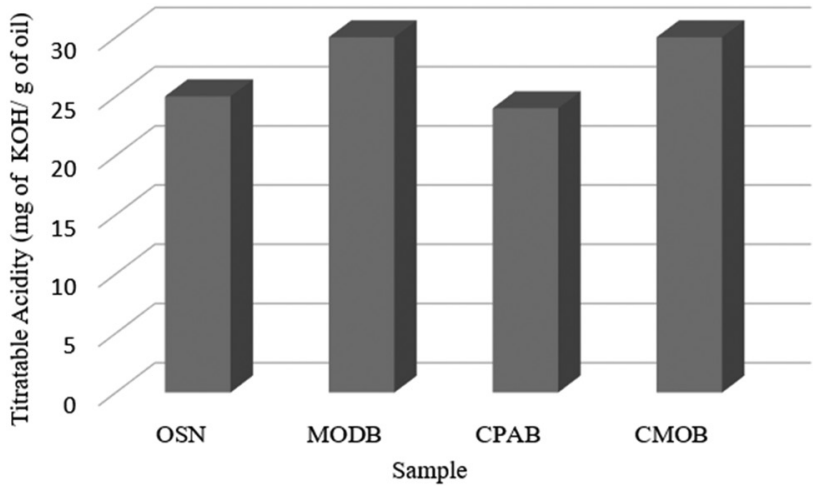

Figure 5. Titratable acidity (in $\mathrm{mg}$ of $\mathrm{KOH} \mathrm{g}^{-1}$ of oil) of neutralized soybean oil (OSN), and neutralized soybean oil bleached by seeds from Moringa oleifera Lam. (MODB); commercial activated charcoal (CPAB); and activated charcoal made of seeds from Moringa oleifera Lam. (CMOB).

may imply that usage of Moringa oleifera Lam. seeds as bleaching agent leads to an increase in the oil's acidity.

$\mathrm{Cecchi},{ }^{20}$ stated that an increase in acidity signals the first stage of vegetable oil degradation which can be caused by TAG hydrolysis, consequently leading to an increase in free fatty acid content, exposure to high temperature and/or light. Moreover, surpassing this first stage leads to the production of reactive oxygen species. Oppositely, a low value for titratable acidity is desirable as it decreases susceptibility to unwanted reactions such as saponification. Therefore, although titratable acidity values for MODB and CMOB were not exceedingly high compared to OSN, the result is unsatisfactory since it negatively affects oil conservation.

\subsubsection{Analysis of fatty acids composition by GC-FID}

Fatty acid composition of neutralized soybean oil (OSN) and bleached soybean oils (MODB, CPAB, and CMOB) were obtained through GC-FID analysis. Results obtained are presented in Table 2. 
Table 2. Fatty acid composition (expressed as relative percentage) of neutralized (OSN) and bleached (MODB, CPAB, and CMOB) soybean oils

\begin{tabular}{ccccc}
\hline Fatty acids & OSN & MODB & CPAB & CMOB \\
\hline $16: 0$ & $11.16^{\mathrm{a}} \pm 0.00$ & $11.07^{\mathrm{ab}} \pm 0.04$ & $11.05^{\mathrm{ab}} \pm 0.03$ & $10.95^{\mathrm{b}} \pm 0.05$ \\
$18: 0$ & $4.48^{\mathrm{a}} \pm 0.04$ & $4.48^{\mathrm{a}} \pm 0.02$ & $4.45^{\mathrm{a}} \pm 0.02$ & $4.33^{\mathrm{b}} \pm 0.02$ \\
$18: 1 \mathrm{n}-9$ & $25.64^{\mathrm{ab}} \pm 0.03$ & $25.76^{\mathrm{a}} \pm 0.06$ & $25.61^{\mathrm{b}} \pm 0.04$ & $25.71^{\mathrm{ab}} \pm 0.04$ \\
$18: 1 \mathrm{n}-7$ & $1.57^{\mathrm{a}} \pm 0.06$ & $1.57^{\mathrm{a}} \pm 0.02$ & $1.60^{\mathrm{a}} \pm 0.07$ & $1.65^{\mathrm{a}} \pm 0.06$ \\
$18: 2 \mathrm{n}-6$ & $50.14^{\mathrm{a}} \pm 0.06$ & $50.08^{\mathrm{a}} \pm 0.10$ & $50.27^{\mathrm{a}} \pm 0.12$ & $50.39^{\mathrm{a}} \pm 0.09$ \\
$20: 0$ & $5.80^{\mathrm{a}} \pm 0.02$ & $5.82^{\mathrm{a}} \pm 0.02$ & $5.83^{\mathrm{a}} \pm 0.04$ & $5.85^{\mathrm{a}} \pm 0.03$ \\
$20: 1 \mathrm{n}-9$ & $0.43^{\mathrm{ab}} \pm 0.01$ & $0.46^{\mathrm{a}} \pm 0.01$ & $0.45^{\mathrm{ab}} \pm 0.01$ & $0.42^{\mathrm{b}} \pm 0.01$ \\
$22: 0$ & $0.22^{\mathrm{a}} \pm 0.00$ & $0.22^{\mathrm{a}} \pm 0.00$ & $0.23^{\mathrm{a}} \pm 0.02$ & $0.22^{\mathrm{a}} \pm 0.00$ \\
$24: 0$ & $0.52^{\mathrm{a}} \pm 0.01$ & $0.52^{\mathrm{a}} \pm 0.02$ & $0.50^{\mathrm{a}} \pm 0.01$ & $0.48^{\mathrm{a}} \pm 0.01$
\end{tabular}

Results expressed as mean \pm standard deviation. Values with different uppercase letters in the same column are significantly different $(\mathrm{p}<0.05)$ by Tukey's test. Samples: OSN: Neutralized soybean oil; MODB: neutralized soybean oil bleached with defatted seeds from Moringa oleifera Lam.; CPAB: Neutralized soybean oil treated with commercial activated carbon; CMOB: Neutralized soybean oil bleached by activated charcoal made of seeds from Moringa oleifera Lam. Fatty acids: palmitic acid (16:0); stearic acid (18:0); oleic acid (18:1n-9); vaccenic acid (18:1n-7); linoleic acid (18:2n-6); arachidic acid (20:00); gondoic acid (20:1n-9); behenic acid (22:0); lignoceric acid (24:0).

As shown in Table 2, nine fatty acids were identified in analyzed bleached soybean oils. Linoleic (16:2n-6) and oleic (18:1n-9) were the main fatty acids present in samples with values ranging from 50.08 to $50.39 \%$ and 25.61 to $25.76 \%$, respectively. Similar fatty acid profiles were also identified by da Silveira et al and Pizzo et al..$^{17-18}$ According to Tukey's test no significant difference was observed among analyzed soybean oils.

\subsubsection{Triacylglycerol composition of bleached soybean oils}

Figure 6 illustrates the mass spectra of OSN, MODB, CPAB, and CMOB acquired via direct infusion ESI(+)-MS comprising the TAG profiles in the region $840-1000 \mathrm{~m} / \mathrm{z}$.
Da Silveira et al., ${ }^{17}$ and Pizzo et al., ${ }^{18}$ evaluated triacylglycerol composition of soybean oils and reported that the majority of peaks appeared in the spectra region between 850 and $950 \mathrm{~m} / \mathrm{z}$. Therefore, our results are in accordance with those reported in the literature. ${ }^{17,18}$ Moreover, all samples exhibited similar lipid profiles which indicate that the oil bleaching did not affect TAG profile.

Jahouach et al. ${ }^{35}$ evaluated the lipid profile of pomaceolive oils bleached using laboratory-activated Tunisian bleaching earth and commercial clays and concluded that the TAG profile of samples was not affected by bleaching. Therefore, since the bleaching process does not affect the lipid profile of samples, seeds from Moringa oleifera Lam. seeds have potential applicability as adsorbent material for bleaching of soybean oil.

A) Neutralized soybean oil

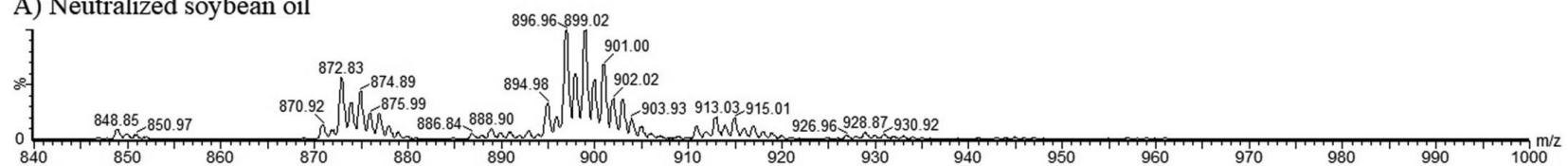

B) Soybean oil bleached with seed coalc

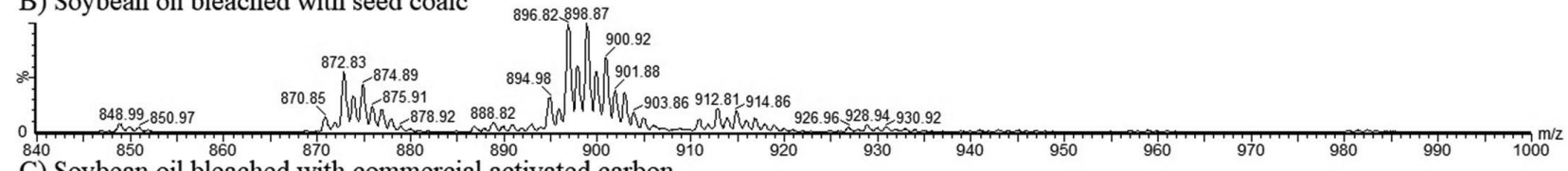

C) Soybean oil bleached with commercial activated carbon

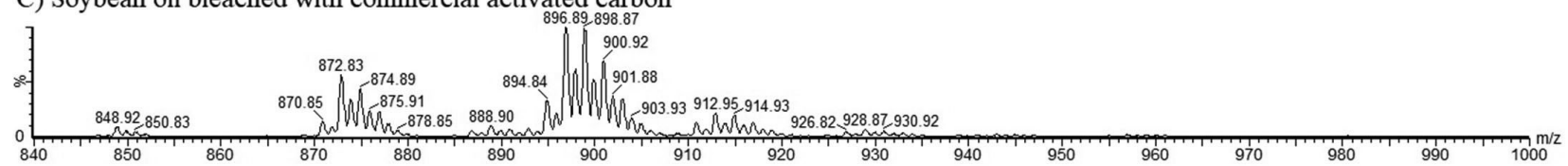

D) Soybean oil bleached with defatted seeds

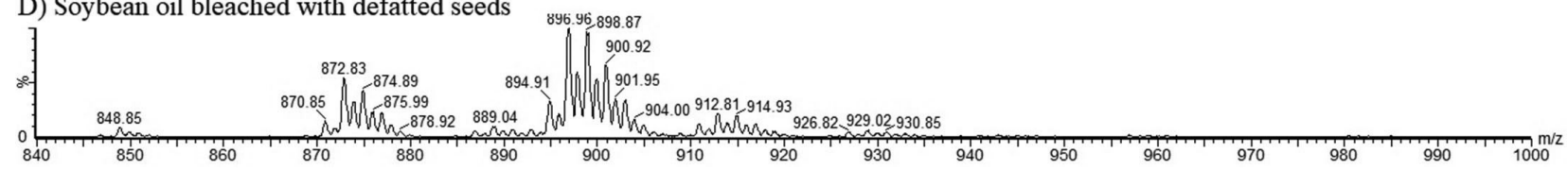

Figure 6. Lipid profile of (a) neutralized soybean oil (OSN) and neutralized soybean oils bleached with (b) defatted Moringa oléifera Lam. seeds, (c) commercial activated carbon, and (d) activated charcoal made from Moringa oléifera Lam. seeds. 


\section{Conclusions}

Characterization of Moringa oleifera Lam. seeds indicates that the seeds have a high lipid, protein, and carbohydrate content. Activated charcoal produced from Moringa oleifera Lam. Seeds showed potential to adsorb soybean oil pigments. Moreover, the bleaching agent did not affect lipid composition of samples, as evidenced by GC-FID and ESI (+)-MS analyses, and displayed higher efficiency than CPA. Thus, our study concludes that charcoal produced from Moringa oleifera Lam. seeds has great potential and could be used on the refinement process of soybean oils.

\section{Acknowledgments}

The authors thank Conselho Nacional de Desenvolvimento Científico e Tecnológico, Brazil (CNPq), Coordenação de Aperfeiçoamento de Pessoal de Nível Superior (CAPES), and Fundação Araucária de Apoio ao Desenvolvimento Científico e Tecnológico do Paraná for their financial support.

\section{Conflict of interest}

No potential conflict of interest was reported by the authors.

\section{References}

1. Ramalho, H. F.; Suarez, P. A. Z.; A Química dos óleos e gorduras e seus processos de extração e refino. Revista Virtual da Química 2013, 5, 2. [Crossref]

2. Abbasi, R.; Gharachorloo, M.; Ghavami, M.; MahmoodFashandi, H.; Mousavi Khaneghah, A.; The Effect of Ultrasonic Waves in Bleaching of Olive and Sunflower Oils and Comparison with Conventional Bleaching. Journal of Food Processing Preservation 2017, 41, 1. [Crossref]

3. Gil, B.; Kim, M.; Kim, J. H.; Yoon, S. H.; Comparative Study of Soybean Oil Refining Using Rice Hull Silicate and Commercial Adsorbents. Food Science and Biotechnology 2014, 23, 1025. [Crossref]

4. Hussin, F.; Aroua, M. K.; Daud, W. M. A. W.; Textural characteristics, surface chemistry and activation of bleaching earth: A review. Chemical Engineering Journal 2011, 170, 90. [Crossref]

5. El-Hamidi, M.; Zaher, F. A.; Comparison Between Some Common Clays as Adsorbents of Carotenoids, Chlorophyll and Phenolic Compounds from Vegetable Oils. American Journal of Food Technology 2016, 11, 92. [Crossref]

6. Beltrame, K. K.; Cazetta, A. L.; de Souza, P. S. C.; Spessato, L.; Silva, T. L.; Almeida, V. C.; Caffeine adsorption in mesoporous activated carbon fibers prepared from pineapple leaves. Ecotoxicology Environmental Safety 2018, 147, 64. [Crossref] [PubMed]

7. Anwar, F.; Latif, S.; Ashraf, M.; Gilani, A. H.; A Food Plant with Multiple Medicinal Uses. Phytotherapy Research: An International Journal Devoted to Pharmacological and Toxicological Evaluation of Natural Product Derivatives 2007, 21, 17. [Crossref] [PubMed]

8. Meneghel, A. P.; Gonçalves, A. C.; Rubio, F.; Dragunski, D. C.; Lindino, C. A.; Strey, L.; Biosorption of cadmium from water using moringa (Moringa oleifera Lam.) Seeds. Water, Air, \& Soil Pollution 2013, 224, 1. [Crossref]

9. Vieira, A. M. S.; Vieira, M. F.; Silva, G. F.; Araújo, Á. A.; Fagundes-Klen, M. R.; Veit, M. T.; Bergamasco, R.; Use of Moringa oleifera Seed as Natural Adsorbent for Wastewater Treatment. Water, Air, \& Soil Pollution 2010, 206, 273. [Crossref]

10. Okuda, T.; Baes, A. U.; Nishijima, W.; Okada, M.; Coagulation mechanism of salt solution- extracted active component in moringa oleifera seeds. Water Research 2001, 35, 830. [Crossref] [ubMed]

11. Alves, V. N.; Mosquetta, R.; Coelho, N. M. M.; Bianchin, J. N.; Di Pietro Roux, K. C.; Martendal, E.; Carasek, E.; Determination of cadmium in alcohol fuel using Moringa oleifera seeds as a biosorbent in an on-line system coupled to FAAS. Talanta 2010, 80, 1133. [Crossref] [PubMed]

12. Gallão, M. I.; Fernandes, L.; Sousa, E.; Avaliação química e estrutural da semente de moringa. Revista Ciência Agronômica 2006, 37, 106. [Link]

13. Bligh, E. G.; Dyer, W. J.; A rapid method of total lipid extraction and purification. Canadian journal of biochemistry and physiology 1959, 37, 911. [Crossref] [PubMed]

14. Agência Nacional do Petróleo, Gás Natural e Biocombustíveis. Available in: $<$ http://legislacao.anp.gov.br/?path=legislacao-anp/ resol-anp/2008/marco\&item=ranp-7--2008>. Accessed in: 5 march 2020.

15. Hartman, L.; Rapid preparation of fatty acids methyl from lipids. Laboratory Practices 1973, 22, 474. [Link]

16. Maia, E. L.; Rodriguez-Amaya, D.; Avaliação de um método simples e econômico para a metilação de ácidos graxos com lipídios de diversas espécies de peixes. Revista Instituto Adolfo Lutz, 1993, 53, 27. [Link]

17. da Silveira, D.; Vágula, J. M.; Figueiredo, I. L.; Claus, T.; Galuch, M. B.; Santos Junior, O. O.; Visentainer, J. V.; Rapid methodology via mass spectrometry to quantify addition of soybean oil in extra virgin olive oil: A comparison with traditional methods adopted by food industry to identify fraud, Food Research International 2017, 102, 43. [Crossref] [PubMed]

18. Pizzo, J. S.; Galuch, M. B.; Santos, P. D. S.; Santos, O. O.; Visentainer, L.; Eberlin, M. N.; Visentainer, J. V. J.; Assement of adulteration os Cosmetics Based on vegetable oils by CG-FID and lipid profile Using Direct Infusion Eletrospray Ionization Mass Spectrometry (ESI-MS). Journal of the Brazilian Chemical Society 2018, 29, 2457. [Crossref]

19. Borges, A. M.; Pereira, J.; Silva-Junior, A.; Lucena, E. M. P.; Sales, J. C.; Estabilidade da pré mistura de bolo com $60 \%$ de farinha de banana verde. Ciência e Agrotecnologia 2010, 34, 173. [Crossref] 
20. Cecchi, H. M.; Fundamentos teóricos e práticos em análises de alimentos, 2a. Ed., Editora Unicamp: Campinas, 2003.

21. Lalas, S.; Tsaknis, J. J.; Characterization of Moringa oleifera Seed Oil Variety "Periyakulam 1". Journal of Food Composition and Analysis 2002, 15, 65. [Crossref]

22. Passos, R. M.; Santos, D. M. C.; Santos, B. S.; Souza, D. C. L.; Santos, J. A. B.; Silva, G. F.; Qualidade pós-colheita da moringa (Moringa oleifera Lam.) utilizada na forma in natura e seca. Revista GEINTEC - Gestão, Inovação e Tecnologias 2012, 3 , 113. [Crossref]

23. Oliveira, J. T. A.; Silveira, S. B.; Vasconcelos, I. M.; Cavada, B. S.; Moreira, R. A.; Compositional and nutritional attributes of seeds from the multiple purpose tree Moringa oleifera Lamarck. Journal of the Science of Food and Agriculture 1999, 79, 815. [Crossref]

24. Biblioteca Virtual em Saúde, Ministério da Saúde. Available in: <http://bvsms.saude.gov.br/bvs/saudelegis/anvisa/2012/ rdc0054_12_11_2012.html>. Accessed in: 25 february 2020.

25. Ayerza, R.; Seed yield components, oil content, and fatty acid composition of two cultivars of moringa (Moringa oleifera Lam.) growing in the Arid Chaco of Argentina. Industrial Crops Products 2011, 33, 389. [Crossref]

26. Torrellas, S. Á.; García Lovera, R.; Escalona, N.; Sepúlveda, C.; Sotelo, J. L.; García, J.; Chemical-activated carbons from peach stones for the adsorption of emerging contaminants in aqueous solutions. Chemical Engineering Jounal 2015, 279, 788. [Crossref]

27. Hsu, S. H.; Huang, C. S.; Chung, T. W.; Gao, S.; Adsorption of chlorinated volatile organic compounds using activated carbon made from Jatropha curcas seeds. Journal of the Taiwan Institute of Chemical Engineers 2014, 45, 2526. [Crossref]
28. Pezoti, O.; Cazetta, A. L.; Souza, I. P. A. F.; Bedin, K. C.; Martins, A. C.; Silva, T. L.; Almeida, V. C. J.; Adsorption studies of methylene blue onto $\mathrm{ZnCl}$-activated carbon produced from buriti shells (Mauritia flexuosa L.). Journal of Industrial and Engineering Chemistry 2014, 20, 4401. [Crossref]

29. Roy, S.; Das, P.; Sengupta, S.; Manna, S.; Calcium impregnated activated charcoal: Optimization and efficiency for the treatment of fluoride containing solution in batch and fixed bed reactor. Process Safety and Environmental Protection 2017, 109, 18. [Crossref]

30. Tarley, C. R. T.; Arruda, M. A. Z.; Biosorption of heavy metals using rice milling by-products. Characterisation and application for removal of metals from aqueous effluents. Chemosphere 2004, 54, 987. [Crossref] [PubMed]

31. Volesky, B.; Sorption and biosorption. BV Sorbex, Inc.: Quebec, 2004.

32. da Silva, K. M. D.; Rezende, L. C. S. H.; Silva, C. A.; Bergamasco, R.; Gonçalves, D. S.; Caracterização físico-química da fibra de coco verde para a adsorção de metais pesados em efluente de indústria de tintas. Engevista 2013, 15, 43. [Link]

33. Elizalde-González, M. P.; Hernández-Montoya, V.; Guava seeds as an adsorbent and as a precursor of carbon for the adsorption of acid dyes. Bioresource Technology 2009, 100, 2111. [Crossref] [PubMed]

34. Ribeiro, E. P.; Seravalli, E. A. G.; Química de Alimentos, 1a Ed, Editora Blucher: São Paulo, 2004.

35. Jahouach, W.; Essid, K.; Trabelsi, M.; Frikha, M. H. J.; Alteration of Chemical Composition and the Oxidative Stability of Bleached Pomace-Olive Oil on Activated Clays. Journal of Agricultural and Food Chemistry 2006, 54, 7137. [Crossref] [PubMed] 